\title{
Labour Migration In The Federal Capital Territory: Examining Its Impact On The Socio-Economic Development Of Gwagwalada Area Council, Abuja.
}

\author{
Igbolo, Magdalene Agbor (PhD) Adaka, Sunday Simeon $(\mathrm{PhD})$ \\ Department of SociologyFaculty of Social ScienceUniversity of Abuja, Abuja.And \\ Department of Sociology Faculty of Social Science Federal university LafiaNasarawa State, Nigeria.
}

\begin{abstract}
Globally, the nexus between migration and development has remained an issue under vigorous academic discourse. Therefore, the process of people migrating to other areas in search of a better life is not a novel one. What has however gained currency is the increasing voluntary movement in the quest for better quality of life by low-skill and low-wage workers as well as high-skill and high-wage workers from less developed rural areas to more developed urban areas, especially among the poor in the developing countries. This is also a situation that has continued to manifest in Gwagwalada, which has resulted in mass influx of people into the area for various reason. This study therefore, is aimed at ascertaining the impact of labour migration on urban development in Gwagwalada Area Council. In carrying out the study, the survey method was adopted, which allowed for the distribution of 150 questionnaires among the sampled population who are residents of Gwagwalada Area Council. Findings revealed that the increase in population has resulted in increased labour force across various occupational competencies in the area; also, there have been increased incidences of crime but with improved commercial benefits; the test of hypothesis revealed that there is a correlation between labour migration and development. The study therefore recommends that government should adopt measures to check the influx of persons from the rural areas by investing in rural communities/ societies. Concerted effort should also be put towards financing the rural enterprises and encouraging effective and efficient agricultural activities by putting in place a National Policy Framework. Rolling Plans should be adopted, as this would assist in increasing the productivity of the rural societies.
\end{abstract}

Key words: Migration; Labour Migration; Development; Rural Area; Urban Area

\section{INTRODUCTION}

The relationship between migration and development has remained an issue under serious academic and intellectual debate. Thus the process of people migrating to other areas in search for a greener pastures/better life is not a new at all. What has however gained momentum is the increasing voluntary movement of people, from all works of life in the quest for better quality of life, especially, from less developed rural areas to more developed urban areas, especially among the poor in the developing countries.In this regard, rural-urban migration results from the search for perceived or real opportunities as a consequence of rural-urban inequality in wealth. This inequality and/or urban bias in development according to research findings over the years results from the overwhelming concentration of wealth, assets, purchasing capacity, economic activities, and variety of services in the urban centers as well as the continued neglect and degradation of rural environments or areas.

Consequently, the effects of rural-urban migration in the rural places of origin of migrants may be manifest in two ways. First, the rural-urban migrants send remittances to their relatives in the rural areas and these remittance-receiving households use the remittances for various purposes. Secondly, these rural-urban migrants execute various rural developmental projects in their rural areas of origin. In Nigeria, most migrants coming from a particular rural community to live in an urban area usually form rural community associations in the urban area. These community associations in the urban areas articulate, from time to time, the developmental needs of their rural communities of origin and contribute resources to execute projects such as road construction and the award of educational scholarships to students in the rural areas.A combination of these rural community projects executed by the rural-urban migrants and the use of remittances by rural remittance-receiving households serve as indicators of the effects of rural-urban migration on the population concerned. In this regard, and in tandem with contemporary praxis, the paradigm shift in the meaning of development emphasizes personal satisfaction consequent on improvement in the quality of life of the "individual" and/or "population" involved in the developmental process. Accordingly, each population ranks community developmental projects and uses of remittances in the order of importance they believe will ensure their satisfaction and happiness. It is 
also the existence of these projects and the uses of remittances derivable from the migration process that reflect the level of socioeconomic development that can be traceable to rural-urban migration. Therefore, the combination of these projects by migrants and the various uses of remittances in the past three years, according to the respondents, are what they see as indicators of development in their rural communities.

\subsection{THE RESEARCH PROBLEM}

Migration is a social issue where people migrate regularly or irregularly for greener pastures outside their places of origin. In the recent times, the International Labour Organisation (ILO) is at the forefront of the campaign that migrant workers should be treated with decorum and their rights given them in the places of their destination.Unlike mortality and fertility, internal migration does not affect the entire population size of a country. But it has a very important role in redistributing the population size between rural and urban areas and between rural areas of low potential and those of higher agricultural and productive potential. One of the most noteworthy demographic phenomena faced by many developing countries in the world is the shortage of labour and food insecurity, and conversely the rapid population growth in the urban centers, which is largely caused by the prevalence of rural-urban migration (Agesa \& Kim, 2001).It is significant to state that most of the urban populations have migrated from other parts of the country particularly from the rural areas. The rate of current urban population growth has reached up to $6 \%$ in many African countries including Ghana (Accra), Nigeria (Lagos), and Kenya (Nairobi), (Dao, 2002), which to a greater extent impacts both in the negative and positive manner on the urban and rural societies.Rural-urban migration has been a challenging issue for policy makers and or governments especially in developing countries. The impact of out-migration on rural livelihoods is a debatable case. Out-migration may result in drastic decrease in the labour which in turn reduces total cropped area and quality of work giving rise to reduced food production and reduced household wealth leading to increased vulnerability in many rural areas which may, bring about food insecurity.

\subsection{RESEARCH OBJECTIVES}

The objectives of this research are to;

i. Determine the causes of labour migration in Gwagwalada Area Council

ii. Examine the migration pattern in Gwagwalada Area Council

iii. Examine the correlation between migration and development in Gwagwalada Area Council

iv. Ascertain the challenges of development and proffer solutions in Gwagwalada Area Council

\subsection{RESEARCH HYPOTHESIS}

1. There has been significant increase in labour migration in Gwagwalada Area Council.

2. There is a significant relationship between labour migration and development in Gwagwalada Area Council.

\subsection{LITERATURE REVIEW: The Concept of Migration}

Migration as a global phenomenon has no acceptable definition. Most definitions use time and space criteria and those which are included in migration process are generally considered to be at least semipermanent and to take place across definite geographical area.Migration can be defined as the movement of people, goods and services within or across national boundaries. The United Nations (UN) defined migration as people moving for various reasons to countries other than their usual residence, for a period of at least twelve months so that the country of destination effectively becomes the new country of usual residence. According to the UN, migration is generally consensual, although it includes movement prompted by a force of socioeconomic or political circumstance. The international convention for the protection of the right of all migrant workers and members of the families, 1990 defined the term "migrant" as a person who is to be engaged, is engaged or has been engaged in a remunerated activity of which he or she is not a national.However, a standard definition of migration was given by the International Organization for Migration (IOM). The IOM defined migration as the movement of person or group of persons, either across international border or within a state. It is a population movement, encompassing any kind of movement of people, whatever is length, composition or causes.Furthermore, the problems encountered in the definition of migration are also reflected in the classification of its various types. This is obvious because unless there is a precise and universally accepted definition of the term migration, it may not be possible to identify the various types of population movements. Migration differs on the basis of duration, distance and organization and this makes classification into mutually exclusive categories rather difficult. This however, has made many writers to simply classify migration as either internal or external. Adebayo (2000) offers the simplest juxtaposition between these two classes of migration by defining internal migration as the population movement from one location to another but within the same geographical boundaries, while international migration (also known as external migration) is the population movement across territorial boundaries. Furthermore, writers on migration are also suggesting that the relative importance of the different types of migration depends on the level of development concerned as well as the 
physical environment. Zilinsky (1971) suggested that in a developing country, rural-urban migration may be dominant while in a developed country, daily commuting to work and urban to urban movement may be more dominant. Adebayo (2000) also supported this view but added that the relative importance of the types of migration do not only depend on the level of development of the country but also on time. According to him, in recent decades, international migration has become relatively more common than internal migration especially in developing countries like Nigeria. In the context of Africa, Gould and Prothero (1975) presented a typology in which time and space provided the primary factors used. Gould and Prothero identified according to time the following grouping of migration; daily, periodic, seasonal, long-term, irregular, permanent, and according to space, rural-urban, rural-rural, urban-rural, urban-urban.However, migration is broadly classified into two (2); immigration and emigration. Emigration can be defined as movement of people, goods and services out of territorial boundary while immigration is the movement of people, goods and services into a particular geographical territory.

\section{The Concept of Labour Migration}

Labour migration is generally defined as a cross-border movement for purposes of employment in a foreign country. However, there is no universally accepted definition of labour migration. The term "economic migrant" is sometimes used as an equivalent to the term labour migrant or migrant worker. However, the two concepts may cover different categories. The term "labour migrant" can be used restrictively to only cover movement for the purpose of employment, while "economic migrant" can be used either in a narrow sense, which includes only movement for the purpose of employment, or in a broader sense that includes persons entering a State to perform other types of economic activities such as investors or business travellers.Classification of labour migration is usually based on the duration of activities, as well as on the distinctions made by receiving countries in their regulatory framework where conditions of admission and stay are established. Depending on the category, procedures of admission can be more or less cumbersome and conditions of stay more or less generous. Persons entering a country for job training are included in some labour migration classifications but excluded from others. Although the purpose of a trainee's movement is not employment, some consider that these schemes should be included, because they are employment-based and can have important labour market implications. Across the world, millions of people are on the move doing jobs ranging from menial labour, such as harvesting, to computer programming. Combined, their numbers would equal the fifth most populous country on the planet. The number of migrants crossing borders in search of employment and human security is expected to increase rapidly in the coming decades due to the failure of globalization to provide jobs and economic opportunities. The ILO sees today's global challenge as forging the policies and the resources to better manage labour migration so thatit contributes positively to the growth and development of both home and host societies, aswell as to the well being of the migrants themselves

\section{The Concept of Development}

In general terms, "development" means an "event constituting a new stage in a changing situation" or the process of change per se. If not qualified, "development" is implicitly intended as something positive or desirable. When referring to a society or to a socio-economic system, "development" usually means improvement, either in the general situation of the system, or in some of its constituent elements. Development may occur due to some deliberate action carried out by single agents or by some authority pre-ordered to achieve improvement, to favourable circumstances in both. Development policies and private investment, in all their forms, are examples of such actions. Given this broad definition, "development" is a multi-dimensional concept in its nature, because any improvement of complex systems, as indeed actual socio-economic systems are, can occur in different parts or ways, at different speeds and driven by different forces. Additionally, the development of one part of the system may be detrimental to the development of other parts, giving rise to conflicting objectives (trade-offs) and conflicts. Consequently, measuring development, i.e. determining whether and to what extent a system is developing, is an intrinsically multidimensional exercise.Similarly, Dudley Seers (1979) was also echoing the subjective concerns of another era in another part of the world when, appalled by the deprivation he saw in the third world, he questioned the meaning of development in his essay 'The New Meaning of Development'. The question to ask about development, he wrote, is: what has been happening to poverty, to unemployment, and to inequality? If all three of these had become less severe during a given period, then beyond doubt it had been a period of development, whereas if one or more of these central problems had been growing worse it would be strange to call the result 'development' even if per-capita income had doubled. Viewed historically, Seers's 'new meaning of development' amounted to a restatement of an older concern and concept. Seers's sentiments came to be shared by various groups, especially by the critics of postwar mainstream development theory and by the advocates of development policies and planning premised on distributive values. The debates on development that went on in the post-colonial era led to a widespread consensus that development could be and should be planned and directed to achieve objectives such as growth 
and distribution. In our times, one author who has consistently and cogently addressed development in relation to human well-being is Amartya Sen, whose contribution to the conceptual framework of UNDP's annual Report on Human Development is well known. If concerned scholars like Seers brought human well-being back into debates on development theory and policy, Igbolo, (2014) has reinforced its centrality by conceptualising it in terms of capability and by suggesting that development could be seen as a process of capability expansion. However, UNDP has played a major role in mainstreaming human development as a concept and popularising the capability approach. It deserves credit for providing us with updated indicators such as the Human Development Index (HDI), Human Poverty Index (HPI) and Gender-related Development Index (GDI), and other valuable information including qualitative accounts of human deprivation and development. The aggregate indicators are helpful in forming an overview of trends in human development.

\subsection{MIGRATION AND SOCIO-ECONOMIC DEVELOPMENT}

Nigeria is among a few countries of the world characterized by contradictory socio-economic development scenarios, a situation where the majority of the people are suffering in the midst of plenty. Despite her enviable human, capital, natural oil and gas resources, the country and its peoples are still classified among the very poor (Nwokocha 2007; Okunmadewa 2001). The rural areas that constitute the majority suffered more from deprivation and neglect than urban areas which perhaps underlay rural poverty and migration of all sorts remain a safety valve. Akinyele, (2005) had remarked that with no fewer than 54\% of Nigerians are living below poverty line.Akinyemi, (2000) explored migration dynamics and changing rural-urban linkages in southwestern Nigeria, using a multi-stage systematic sampling technique and modelled the linkages through the use of logistic regression model to examine the correlation of migrants to rural- urban linkages in terms of infrastructure ownership and development in both areas of participation in homestead association, intention to return home, and political participation. The study revealed a strong relationship between migrants' empowerment and ruralurban linkages. Migrants with higher income as well as high educational status are more likely to support homestead. Those with lower status are less likely to contribute to the homestead. Those who are empowered have very high tendencies to influence rural development. They are more likely to participate in village associations, politics, own property in their home towns.Gbemiga, (2005) investigated socio-economic factors influencing movement of people from urban centres to rural areas in Nigeria with particular focus on Oyo State of Nigeria. Purposive sampling technique was used to sample 160 migrants in rural areas for the study. Data were generated from the respondents using interview schedule. The results showed that most of the respondents left the urban centres for the rural areas because of their inability to secure jobs, transfer to rural areas in their places of work, retirement and high cost of living in the urban centres. Moreover, there was a significant relationship between lengths of stay of migrants in the rural areas and their ages; the lengths of stay on migration by the single, married, widowed and divorced migrants since the calculated F-ratio (3.04) exceeds the tabulated F- ratio (2.74). It is recommended that government should encourage the drift of people to rural areas by making available basic amenities that would encourage the prospective migrants to remain in rural areas.Taylor and Dyer (2006) employed micro-economy modelling techniques to explore the short term and long-term impacts of international migration on rural communities in Mexico. The findings illustrate the complex ways in which international migration influences rural economies, stimulating some production activities while causing others to contract, and transforming the structure of the rural economy over time. The findings presented here illustrate the importance of indirect effects of international migration on sending economies and it includes general-equilibrium wage and price effects as well as dynamic investment effects.Shettima (1997) remarked that forced migration results either from a planned or unplanned movement following either civil strife or collapse of infrastructure most especially water dams, bridges and other buildings which can result in relocation people. This type of movement often raises major concerns about human rights and involved compensation claims in developed economies but hardly documented in Nigeria partly because it occurs mainly in rural areas and the attenuated state of the statistical services. Moreover, there are people who have been forced to migrate from their home and cannot return for fear of persecution because of their race, religion, nationality, and possibly their membership in a social and political organization. This set of people is known as refugees.However, none of the recent studies accessed, (Akinyemi, 2000; Okunmadewa, 2001; Afolabi, 2004; Gbemiga, 2005; Akinyele, 2005; Taylor and Dyer, 2006; and Abuh, 2011; Shettima, 1997; and Nwokocha, 2007) paid attention to how rural-ward migration affects economic development particularly in Jos South local government area of Plateau State and this constitutes the gap in knowledge that the study intends to fill.

\subsubsection{RURAL-URBAN MIGRATION AS A MAJOR TREND OF MIGRATION IN NIGERIA}


Rural to urban migration has historically been an important part of the urbanization process and continues to be significant in scale in developing countries. Internal migration accounted for at least half of all urban growth in Africa during the 1960s and 1970s and about 25\% of urban growth in Africa in the 1980s and 1990s (Brockerhoff, 1995). In Brazil, it is estimated that over 20 million people moved from rural to urban areas between 1950s and the 1970s. Similarly, around 21 million people in India (30\% of the national urban growth) moved from rural to urban areas in 1990s (Census of India, 2005).The decision to migrate involves 'push factors' which force migrant out of the rural areas as well as 'pull factors' which attracts migrants to urban areas. The earlier model developed by Harris and Todaro (1976) explains rural-urban migration as a response to the expected rather than current income differential between rural and urban areas. In other words, workers will continue to migrate from rural to urban areas until wages they expect to earn in urban areas are equal to the wages they expect to earn in the rural areas. Numerous empirical research have built on this foundation to examine individuals' motivation to migrate from rural to urban areas and majority reveal that the primary motivation is indeed economic considerations (Connell et al 1977, Baril et al 1986). Some studies indicate that economic push factors (for example lack of rural credit, unemployment, lack of land, general rural poverty) are most important while others suggest that economic pull factors (e.g. perception of high wages from urban employment) are predominant. A number of other motivations for rural-urban migration including educational opportunities offered in urban areas, marriage and joining the family already at the destination are cited in the literature. Also, a few studies suggest that rural-urban migration is facilitated by the concentration of migrants of same origin in the destination city (Mora \& Taylor, 2005).Migrants often have a difficult time finding jobs in cities as they are more likely to have only imperfect information about the type or quality of job opportunities they face (Banerjee, 1984). To find a job, they usually go through friends, family and other informal networks (Banerjee and Bruce, 1995). In addition, Yamauchi and Tanabe (2003) argue that finding a job is often facilitated if there is a large network of people from the same origin as the migrant at the destination but this could also reduce the probability of finding a job if these migrants have to compete for the same jobs. It is also important to understand how rural-urban migration evolves over the development process but the available research is limited and inconclusive. The UN (1980) estimates a significant positive relationship between ruralurban out migration rates and the standard of living of citizens. On the other hand, Ledent (1982) concludes that the evolution of rural-urban migration rate and standard of living follows the following pattern "it first increases, reaches a maximum and then decreases towards a value of zero". The existing research on the impact of ruralurban migration on development in Nigeria is also limited and inconclusive. Fadayomi (1998) reveals that internal migration has a negative impact on the quality of rural life because it reduces the number of individuals in rural areas. Migration of young adults from the rural areas places a greater burden on the remaining farmers as they now have to work harder and longer to cover the same area of land thus depriving them of some of their leisure time. On the other hand, Ijere (1994) reveals that rural-urban migration has a positive impact on urban growth and social development and this helps generate employment, educational facilities and transportation infrastructure for the migrants. However, this argument is questionable when one considers the fact that it has been shown that urban areas in Nigeria are plagued with social problems, unemployment, poverty and deficit of infrastructure.However, the burden of rural-urban migration in Nigeria is multifaceted and intertwining. As such, an analysis of one decomposable component or consequence, such as unbearable population density, impinges on other issues within the identifiable cycle of burdens. For instance, in examining the immediate effect of rural to urban migration, which is increase in population or at the extreme its explosion, various other subsequent effects are expected to be considered. Population explosion activates the housing challenge both at micro family and macro society levels. Congestion in households and communities has implications for both the health and psychology of victims. Nigerian cities such as Lagos, Port-Harcourt, Kano, Onitsha among others are characterized by human traffic, vehicular congestions, environmental pollution, consistent in-migration and spurious expansion of territories to accommodate human additions.Lagos is the mostly affected city in term of unplanned growth, around $85 \%$ of the country's industrial activity is located in Lagos and it is one of the fastest growing cities in the world. Its annual growth rate was estimated at almost 14\% during the 1970s and its current population is estimated to be 15 million (Census, 2006). Projections suggest that by 2020 it will be the third biggest in the world (USAID, 2002). Rural-urban migration has a significant impact on unemployment levels of the destination cities. Between 1998 and 1999, urban unemployment rose from 5.5\% to 6.5\%, a rate higher than the national unemployment which increased from $3.9 \%$ to $4.7 \%$ during the same period (USAID, 2002)Unplanned population increases in most cities explain infrastructural decay in relevant contexts. This is especially the case in Nigeria where maintenance of existing amenities, which ab-initio are haphazardly situated due to unprecedented corruption and biased award of contracts, is not prioritized (Okafor, 2005). It is interesting to note that most roads in the country are impassable, hospitals lack human and necessary material resource, schools are dilapidated and electricity supply is very far from stable - in most rural communities though, none of these infrastructures exists. The people's agony is visible in frustrations arising from avoidable diseases and deaths, lack of access to portable water, subsistent economic activities, various kinds of unemployment, child 
abuse in all its ramifications and dwindling focus on societal norms and values (Nwokocha, 2007).Rural communities share this burden through loss of manpower necessary for agricultural activities and production. The impoverishment of rural areas in Nigeria is partly explainable by out-migration of able youths in search of employment in cities. Consequently, agriculture which prior to discovery of oil was the mainstay of Nigeria's economy was far relegated to the background leading to the country's mono-economy status.Overdependence on oil, it is argued here, has led to employment crisis and avoidable importation of agricultural products, which together have over the years had negative net effect on local industries and productions as well as international trade balances. Several analyses of Nigeria's economy insist that petroleum resources have been more of a curse rather than a blessing to the development of the country (Iwayemi, 2006)It is imperative to note that some migrants overcome their locality-imposed powerlessness in new destinations, while a large majority of others become more impoverished to the point of becoming social misfits otherwise known as "area boys and girls". Another burden imposed by rural to urban migration is the increasing number of cohabitation and consensual unions that results among the married and the not yet married. Although it could be argued in some quarters that such union, especially when it involves people from different ethnic backgrounds, could have positive implications for the country's unity at macro level, the negative consequences on existing marriages and family unity at the micro are enormous. The above issues constitute the burden and in some cases agony of rural-urban migration in Nigeria for which organized critical thinking and context specific intervention strategies are essential.

\subsubsection{RURAL-URBAN MIGRATION AND UNDERDEVELOPMENT IN NIGERIA}

Migration, especially the rural-urban migration has been seen as one of the mechanism that has added to the underdevelopment quagmire facing a plethora of developing countries especially in Nigeria. Although it is quite debatable that rural-urban migration through the instrumentality of remittance of money by out-migrants to their relatives has helped the latter to enjoy somewhat better socio-economic livelihood in their rural communities. However, this section provided a nuance perspective to the negative effects of rural-urban migration on the underdevelopment of the rural areas.Economically, it has been held that rural-urban migration of skilled and the educated from the rural areas deprived those areas of human capital so badly needed for economic development. Sustained growth and development (elimination of poverty) will for a long time remain elusive in the rural areas until they (rural areas) succeed in building, retaining and nurturing the human capital vital for grooming the area. Although scanty documented data exists on the impact of rural brain drain on rural areas, there is no doubt that they are losing on a daily basis sizeable number of her human capital to the urban centers.Iyorakpo, (2011) has noted that migration from rural into urban areas tend to deplete the agricultural labour force as it is the able bodied young men who usually move. It is instructive to note that rural area is the predominant food and fiber producing sector of the Nigerian society with about 90 percent of the country's food produced by small scale farmers residing there as observed by Global Action on Aging (Chikere, 2014). With no commensurate substitution of capital in place of the displaced labour, agricultural productivity tends to fall in the source region and thus worsening the already fractured rural sector. Degeneration of traditional skills and knowledge has also been accentuated by rural-urban migration. Crafts such as pot making, mat making, weaving, bone-setting, trado-medicine, etc has provided a means of livelihood and sustenance to individuals with such skills in the rural areas. These skills could be used to establish small scale industries where other local skills could be harnessed and effectively developed. The effect of out-migration from rural to urban areas has been the degeneration and abandonment of these traditional skills which act as viable developmental options in the long run.Socio-culturally, rural-urban migration could account for the lost of the cultural identity and heritage of the local people. Culture as that complex whole encompasses the blueprint and social road map for living. In many rural Nigerian communities, there are notable exotic places that have attracted both national and international attention. Specifically, as it relates to cultural tourism, such places like the famous Oguta Lake resort in Oguta and the Legendary Ogbunike Cave in Oguta, Imo State and Enugu state Southeast Nigeria respectively, among others could generate tremendous revenue to the local people and as well project their culture positively. But before this could be done in the first place, enabling local environment that encourage the rural people to stay and promote such cultures should be put in place. In situations where the local guides in such tourists centers migrate to urban areas in search of better employment that will greatly affect that sector adversely. It is instructive to note that no society can develop outside its own culture and the preservation of culture is a sine quo non for sustainable rural development.Rural-urban migration is also associated to what Okereke, (2003) has termed 'ghost' rural villages. In most rural communities due to the mass influx of youths and able bodied individuals to cities, the area has been left for the elderly and children. Hence, social life has remained dull and unattractive in the rural communities. Knodel and Saengtienchac (2005) noted that the departure of adult children has reduced their availability to provide assistance in the daily functioning of their parents' households or personal care for those who become frail or suffer chronic illness.Lastly, one should remember the crucial role the youths play in providing community security for lives and property. In most 
Nigerian communities where access to formal law enforcement agency (police) is not available due to its remoteness, the youth vigilante groups usually fill the security vacuum. As earlier noted the quest for better employment and the fuss about the urban centers as the cynosure of development, a preponderant number of youths usually abandon their villages and the crucial role of securing lives and property of the ruralites

\subsubsection{FACTORS AFFECTING RURAL-URBAN MIGRATION}

Three categories of factors are perceived as important reasons for rural-urban migration. The first set is related to the need for education and acquisition of skills in various vocations. The second set relate to the absence of desirable job opportunities in rural areas. These include the absence of employment, absence of industries and companies and boredom in agriculture. The third set of factors is social, such as inadequate amenities and expulsion from rural areas due to an offence or crime committed by the migrant. The first two sets of factors are common in rural-urban migration literature as factors responsible for the movement of migrants. Of the social factors are, however, only inadequate social amenities has a fair mention in the literature (Mabawonku,1973; Sabot, 1972).Similarly, Iyorakpo (2011) has noted earlier that migration (rural-urban) is basically a reflection of the imbalance in opportunities and life chances which exist between the rural-urban areas. The existing dissatisfying state of affairs in the rural areas are what compel the ruralites to migrate to urban areas and are known as push factors. These push factors are:

\section{Inadequate Supply of Social Infrastructure}

For many people in Nigeria, life in the rural areas is not adequately supported by the existing lifesupporting social amenities like educational facilities (primary schools, secondary schools, vocational and technical schools, adult education, etc), health facilities (hospitals, maternity centers, etc), communication facilities (internet services, Global System for Mobile (GSM), etc), electricity and water supply (Ekong, 2003). For instance, most rural dwellers in Nigeria obtain water from streams, wells, rivers, shallow ponds or rain unlike what obtains in the cities where pipe borne water and bore-hole water supply are significantly provided. Iyorakpo (2011) observed that water borne diseases like cholera, dysentery, "typhoid" suffered by the ruralites can be attributed to inadequate supply of clean portable water.Similarly, electricity supply for lighting, small scale industries, recreation and other uses that is very vital to raising the rural quality of life is equally inadequate or non-existent. With the rural population constituting $51.26 \%$ of the total population of Nigeria. World Bank, (2010) estimated that only $34.58 \%$ of Nigeria's rural populations have access to electricity. This ugly situation and many others have been the precipitating factors pushing people to the cities.

\section{Inadequate Supply of Physical Infrastructure}

Physical infrastructure in this sense, include transportation facilities (roads, bridges, ferry services, ports), storage facilities (silos, warehouses, cribs, etc), processing facilities, irrigation, flood control and water processing facilities and soil conservation facilities (Iyorakpo, 2011).Generally speaking, development in Nigeria as it concerns the provision of physical infrastructure is skewed to favour the urban areas. Among the rural dwellers in the riverine areas, transportation for instance, still depends largely on dugout canoes or sometimes motorized propellers. Port facilities have been greatly developed in major port towns like Lagos, Warri, Port Harcourt and Calabar. However, these facilities have not been developed for the direct use of rural people but to serve as terminals for international trade. The ruralites who have to make use of rivers often use local communal landing points along creeks or abandoned bases such as Ifiayong, Ikot Abasi, Eket, Itu, etc which were important departure points for primary export produce during the colonial days (Iyorakpo, 2011).

\section{Inadequate Allocation of Institutional Infrastructure}

Institutional infrastructure such as credit and financial institutions, agricultural research institutions, agricultural and industrial extension services and marketing services among others are essential for the direct development of the rural areas. It is however, unfortunate that most of these institutional infrastructures especially credit and financial institutions are completely lacking in the rural areas. Rural farmers require credits (loans) from banks to engage in somewhat large- scale farming but the absence of such services or the stress of going to the cities to access the services have left them disenchanted and subsequently enmeshed in subsistence living. To these ruralites, life in the cities remains the only closure to escape the harsh realities of rural life.

\section{Unbalanced Employment Opportunities}

This is one of the crucial reasons why people migrate to cities in Nigeria. According to Todaro in World Bank, (2013) in his labour migration and employment model also propounded the rural-urban wage differential theory, which opines that the decision to migrate from the rural to the urban area is to achieve high urban pay as compared to the low rural pay. People migrate to cities in search of better job opportunities that 
will enhance their standard of living. Such opportunities exist in political capitals, industrial and commercial centers in cities.

\section{Unforeseen Natural and Social Events}

Decision to migrate could be spontaneous and strongly related to the disruption of the rural economy. Such spontaneous decision as noted by Nwanna (2004) and Adewale (2005) could be as a result of natural disaster like flood, drought, land slide, erosion, earthquake, insect and pest infestation, escape from political instability, rights abuses, communal clashes, family disputes, outbreak of war and other adversities. A case in point in Nigeria is the activities of Boko Haram insurgency where many rural people have been displaced and turned into refugee in their own country. To this effect, many have migrated to the more urban areas for safety.

\subsection{THEORETICAL FRAMEWORK}

\section{Todaro's Theory of Labour Migration}

The principal motive behind migration has been centred on the wage differential among regions. This is well-established in migratory studies (Todaro, 1976) explained that as long as there are differences in wages earned, labour would move from low wage region to a higher wage area. This is the driving force behind ruralurban migration since there is inequality between the rural and urban sector real wage rates. The decision to migrate is often based on the comparison between the returns to labour in the rural agricultural sector and wage rate in the manufacturing and service sectors of the urban economy. Also, the number of job vacancies in the urban area is often considered. A larger wage gap between the two areas results in a greater incentive for rural workers to migrate to the cities. Moreover, the rural-urban income divide arising from an institutionally urban minimum wage imposed by the government or negotiated by trade unions can create opportunity for rural labour to migrate into the urban areas.The centripetal and centrifugal forces otherwise known as push-pull are factors that could either attract or discourage people to migrate. Ghaffari and Singh, (2000) remarked that the push factors are those that compel a person due to different reasons to leave that place and go to some other place. For instance, low productivity, unemployment and underdevelopment, poor economic conditions, lack of opportunities for advancement, exhaustion of natural resources and natural calamities may compel people to leave their native place in search of better economic opportunities. In most developing countries, due to population explosion land-man ratio has declined resulting in significant increase in unemployment and underemployment. The pull factors refers to those factors which attract the migrants to an area such as bright opportunities for better employment, higher wages, facilities, better working conditions and amenities. De Haas, (2007:13) observed that there is generally city ward migration where rapid growth of industry, commerce and business take place. Sometimes the people are also attracted to cities in search of better cultural and entertainment activities thus, pull factors operate not only in the rural-urban migration, but also in other types of domestic as well as international migration. Those who are pushed into migration are simultaneously pulled by the expectation of finding something better elsewhere. De Haas (2008) described this migration theory as the most comprehensive attempt at integrating both endogenous and exogenous factors together.Similarly, the situation of labour migration in Gwagwalada Area Council follows the same pattern as postulated by Todaro (1976). This is because the current spate of population explosion in the area can only be attributed to the growing concern and quests of the people in other societies (particularly, the rural societies) who have continued to move in their numbers into the city centre of Gwagwalada, in the quest for better condition of living, better employment opportunities and better wage conditions. This has significantly impacted on the socio-economic and political lives of the people. In fact, it is acknowledgeable to reiterate the fact that the space and spate of development has significantly been affected; as there is the expansion of available market population, labour force, increase in economic indices and a concomitant impact on the general infrastructure.

Thus, in consonance with Todaro's perspective, it can be concluded that people migrate due to compelling circumstances which pushed them out of the place of origin or they are lured by the attractive conditions in the new place.

\section{METHODOLOGY}

The study area of this research is the Gwagwalada Area Council of the FCT. Gwagwalada Area Council of the six Area Councils in the FCT, the council was created in October, 1984. The council is strategically located in the heart of the Federal Capital; it has the third largest economic and human capital base after AMAC.

The population of Gwagwalada Area Council was put at 158,618 (NPC, 2006) but with the trends of demolition of structures in the city centre of Abuja over the years, the population has inflated to over 1,000,000 residents (ACSS, 2015) owing to the continuous influx of people. Also, just like every other area council in the federal capital, the area council is made up of heterogeneous population which cuts across various ethnic and religious backgrounds, which no doubt reflects the level of ethnic imports as a result of migration. The study adopted a survey method. A selected sample from the total population of Gwagwalada Area Council was selected and 
distributed with questionnaire. This research technique will be applied here due to its variability in using a sample drawn to represent the element within the Area Council, (which is the universe of this study). The population of the Area council is well over 1,000,000, which cut-across 10 wards in the area council, namely; Zuba, Ibwa, Dobi, Kutunku, Tunga Maje, Gwako, Paikon-kore, Ikwa, Quarters and Central wards. However, the population is a composition of aggregate proportion of Muslims and Christian residents of both male and female gender from diverse ethnic backgrounds of the country. The study adopts the systematic random sampling technique in order to successfully carry out the field survey where questionnaires where distributed to 150 residents in the area council. Systematic random sampling is the random sampling method that requires selecting samples based on a system of intervals in a numbered population. The researcher administered a survey questionnaire to every fourth person he comes in contact with. The fact that questionnaire would be administer to every fourth person in the population is what makes the sampling systematic because there is an interval system. The systematic random sampling technique is preferred because of its simplicity. It allows the researcher to add a degree of system or process into the random selection of subjects. Interviews were also conducted with key persons in the Area council in order to buttress the validity and reliability of the information obtained from the questionnaire. Tabular and mean average calculation method was used in order to make presentation more adequate and meaningful without losing both the qualitative and quantitative information available for the research. The above stated method of analysis was chosen because of its simplicity, ease of comprehension and reliability for the achievement of desired understanding without loss of context and meaning. Again the chi-square test of significant relationship was employed in order to test the earlier stated hypothesis.

\section{DATA ANALYSIS AND DISCUSSION}

This section deals with the organization, presentation, analysis and interpretation of data collected from the field. Data was collected from respondents across Gwagwalada Area Council in order to assess the relationship between labour migration and urban development in Gwagwalada Area Council. Data generated from the questionnaire were organized and presented in tabular form to enhance the ease of comprehension among the classes of data. Data are presented in univariate tables showing only one variable e.g. sex of respondents, age, religion etc as well as multivariate tables showing comparison between two variables.

IV. ANALYSIS OF DATA

Table 1: Responses on residence status in Gwagwalada Area Council?

\begin{tabular}{|l|l|l|}
\hline Responses & Frequency & Percentages (\%) \\
\hline Yes & 91 & $61 \%$ \\
\hline No & 59 & $39 \%$ \\
\hline Total & 150 & $100 \%$ \\
\hline
\end{tabular}

Source: field survey, 2016

The above table shows that $91(61 \%)$ of the respondents claimed to have migrated to Gwagwalada Area Coucil; while $59(39 \%)$ of the respondents claimed not to be migrants which makes them indigenes of the area. This therefore implies that a greater majority of the respondents are migrants.

Table 2: Reason for migrating to Gwagwalada Area Council

\begin{tabular}{|l|l|l|}
\hline Responses & Frequency & Percentages (\%) \\
\hline Education & 24 & $26 \%$ \\
\hline Marriage & 9 & $10 \%$ \\
\hline Employment & 29 & $32 \%$ \\
\hline Economic Activity & 17 & $19 \%$ \\
\hline Health and other Amenities & 12 & $13 \%$ \\
\hline Total & 91 & $100 \%$ \\
\hline
\end{tabular}

Source: field survey, 2016

The above table is an extract from the responses of respondents. It shows that $24(26 \%)$ of the respondents claimed to have migrated to Gwagwalada in the quest for education; 9 (10\%) for marriage; 29 (32\%) for Employment; $17(19 \%)$ for better Economic Activity; while $12(13 \%)$ of the respondents migrated to Gwagwalada in the quest for good Health facilities and other Amenities. However, based on the summation of the responses, it is significant to imply that a whole lot of person migrated to Gwagwalada Area Council for diverse reasons, but mostly in the quest for education, employment and for better economic fortune.

Table 3: Respondents views on the increase of migrats into Gwagwalada

DOI: 10.9790/0837-2202020419 $\quad$ www.iosrjournals.org $\quad 12 \mid$ Page


Labour Migration In The Federal Capital Territory: Examining Its Impact On

\begin{tabular}{|l|l|l|}
\hline Responses & Frequency & Percentages $(\boldsymbol{\%})$ \\
\hline Yes & 86 & $57 \%$ \\
\hline No & 64 & $43 \%$ \\
\hline Total & 150 & $100 \%$ \\
\hline
\end{tabular}

Source: field survey, 2016

From the above table, $86(57 \%)$ of the respondents believed that there has been increased migration into their Gwagwalada; While, $64(43 \%)$ of the respondents do not believe that there has been any increase in migration into their Gwagwalada. This therefore implies that there has been increased influx of persons from various localities into the Gwagwalada Area Council for various reasons.

Table 4: Major pull factors of migration into Gwagwalada Area Council

\begin{tabular}{|l|l|l|}
\hline Responses & Frequency & Percentages (\%) \\
\hline Search for employment & 73 & $49 \%$ \\
\hline Available Infrastructures & 21 & $14 \%$ \\
\hline Better Education Services & 24 & $16 \%$ \\
\hline $\begin{array}{l}\text { Healthcare Facilities and } \\
\text { ways of life }\end{array}$ & 32 & $21 \%$ \\
\hline Total & 150 & $100 \%$ \\
\hline
\end{tabular}

Source: field survey, 2016

From the above table it shows that $73(49 \%)$ of the respondents attribute the pull factor of migration into Gwagwalada to the search for employment; 21 (14\%) of the respondents attribute the pull factor of migration into Gwagwalada to the available infrastructure in the area; $24(16 \%)$ of the respondents attribute the pull factor of migration into Gwagwalada to good educational services; while $32(21 \%)$ of the respondents attribute the pull factor of migration into Gwagwalada to the available healthcare facilities and ways of life. Therefore, base on the various responses it is safe to imply that the major pull factor of migration into Gwagwalada Area Council is the search for employment and better healthcare services.

Table 5: Responses on the impact of migration on economic activities in Gwagwalada Area Council

\begin{tabular}{|l|l|l|}
\hline Responses & Frequency & Percentages (\%) \\
\hline Yes & 83 & $55 \%$ \\
\hline No & 67 & $45 \%$ \\
\hline Total & 150 & $100 \%$ \\
\hline
\end{tabular}

Source: field survey, 2016

The above table shows that $83(55 \%)$ of the respondents believe that the migration of people into Gwagwalada has boost the economic activities of the area; while $67(45 \%)$ of the respondents do not believe that the migration of people into Gwagwalada has boost the economic activities of the area. The summation of the responses implies that the economic activities of Gwagwalada Area Council have experienced a boost as a result of the influx of persons into the area.

Table 6: Responses on the Impact of migration on the availability of labour in Gwagwalada Area Council

\begin{tabular}{|l|l|l|}
\hline Responses & Frequency & Percentages (\%) \\
\hline Yes & 91 & $61 \%$ \\
\hline No & 59 & $39 \%$ \\
\hline Total & 150 & $100 \%$ \\
\hline
\end{tabular}

Source: field survey, 2016

The above table shows that $91(61 \%)$ of the respondents believe that the migration of people into Gwagwalada has impacted on the availability of labour; while $59(39 \%)$ of the respondents do not believe that the migration of people into Gwagwalada has impacted on the availability of labour. From the greater percentage of responses, it therefore implies that the influx of people into Gwagwalada Area Council has increased the available labour force in the area which has also made cheap the available pool of manpower labour in the area.

Table 7: Areas/occupation in which labour is readily available

\begin{tabular}{|l|l|l|}
\hline Responses & Frequency & Percentages (\%) \\
\hline Skilled Labour & 51 & $34 \%$ \\
\hline
\end{tabular}


Labour Migration In The Federal Capital Territory: Examining Its Impact On

\begin{tabular}{|l|l|l|}
\hline Semi-Skilled Labour & 73 & $49 \%$ \\
\hline Unskilled Labour & 26 & $17 \%$ \\
\hline Total & 150 & $100 \%$ \\
\hline
\end{tabular}

Source: field survey, 2016

The above table shows that $51(34 \%)$ of the respondents claimed that the available labour is the skilled labour; 73 (49\%) of the respondents claimed that the available labour is the semi-skilled labour; while 26 (17\%) of the respondents claimed that the available labour is the unskilled labour. This therefore implies that the available labour does not require much skill or professional qualification, and this could be in the area of manial jobs and private organizational set-up.

Table 8: Negative implications of the increased population in Gwagwalada Area Council

\begin{tabular}{|l|l|l|}
\hline Responses & Frequency & Percentages $(\%)$ \\
\hline Yes & 126 & $84 \%$ \\
\hline No & 24 & $16 \%$ \\
\hline Total & 150 & $100 \%$ \\
\hline
\end{tabular}

Source: field survey, 2016

The above table shows that $126(84 \%)$ of the respondents claim that the increase in population has been accompanied with negative implications; while $24(16 \%)$ of the respondents claim that the increase in population has not had negative implications. These negative implications are unemployment $38(30 \%)$; overpopulation and congestion in the area $31(25 \%)$; increased spate of criminal activities; $30(24 \%)$ high cost of living; while $27(21 \%)$ of the respondents believe that the increase in population has resulted in increased unemployment in the area. The implication therefore is that population growth in Gwagwalada Area Council has no doubt created the avenue for the occurrence of these social problems and has also heightened the spate of its occurrence. Moreover one hundred and seven $(71 \%)$ of the respondents believe that government has not been doing enough in employing the growing population in the area; while 43 (29\%) of the respondents believe that government has been doing enough in employing the growing population in the area, which indicates that government has not provided enough employment opportunities that could adequately employ the teeming population in Gwagwalada Area Council.

Table 9: Strategies for harnessing the teeming population

\begin{tabular}{|l|l|l|}
\hline Responses & Frequency & Percentages (\%) \\
\hline Establishment of Industries & 59 & $39 \%$ \\
\hline $\begin{array}{l}\text { Revitalization of the } \\
\text { Agricultural Sector of the } \\
\text { Area }\end{array}$ & $19 \%$ \\
\hline $\begin{array}{l}\text { Vocational Trainng and } \\
\text { Empowerment Schemes }\end{array}$ & 30 & $20 \%$ \\
\hline $\begin{array}{l}\text { Financial Empowerment to } \\
\text { Start up Businesses }\end{array}$ & 33 & $22 \%$ \\
\hline Total & 150 & $100 \%$ \\
\hline
\end{tabular}

Source: field survey, 2016

The above table shows that 59 (39\%) of the respondents believe that in order to harness the growing population in the area, government should establish industries that would gainfully employ the growing population; 28 (19\%) of the respondents believe that government should revitalize the agricultural sector in order to gainfully employ the growing population; 30 (20\%) of the respondents believe that government should embark on vocational training and other empowerment schemes in order to make the population productive enough; while $33(22 \%)$ of the respondents believe that government should provide the financial capacity for the population to engage in private businesses. However, based on the summation of the responses, it is significant to imply that all these strategies have been suggested as veritable measures towards harness the growing population in the area.

Table 10: Strategies adopted to reduce the rate of migration into Gwagwalada Area Council

\begin{tabular}{|l|l|l|}
\hline Responses & Frequency & Percentages (\%) \\
\hline $\begin{array}{l}\text { Provision of Infrastructure across } \\
\text { other communities }\end{array}$ & 63 & $42 \%$ \\
\hline
\end{tabular}




\begin{tabular}{|l|l|l|}
\hline $\begin{array}{l}\text { Provision of Rural Healthcare } \\
\text { system and Housing }\end{array}$ & 29 & $19 \%$ \\
\hline $\begin{array}{l}\text { Provision of Employment } \\
\text { Opportunities across Societies }\end{array}$ & 31 & $21 \%$ \\
\hline $\begin{array}{l}\text { Resuscitation of the Agricultural } \\
\text { Sector }\end{array}$ & 27 & $18 \%$ \\
\hline Total & 150 & $100 \%$ \\
\hline
\end{tabular}

Source: field survey, 2016

The above table is an extract from the open responses of respondents. It shows that $63(42 \%)$ of the respondents suggest the provision of social infrastructure across societies in order to mitigate the migration of people into Gwagwalada; 29 (19\%) of the respondents suggest the provision of rural healthcare sytem and housing particularly rural societies in order to mitigate the migration of people into Gwagwalada; 31 (21\%) of the respondents suggest the provision of employment opportunities particularly in rural societies in order to mitigate the migration of people into Gwagwalada; while $27(18 \%)$ of the respondents suggest the resuscitation of the agricultural sector as a measure for engagement in order to mitigate the migration of people into Gwagwalada. However, based on the summation of the responses, it suffices to imply that all these strategies are significant in reducing the spate of migration into Gwagwalada Area Council. This is because a whole lot of people migrate in the search for better opportunities for survival, however when all these opportunities are provided at their domain there would be no need for them to migrate to other places.

\section{TEST OF HYPOTHESES}

In order to determine the true position of the hypotheses stated earlier, the study employed the pearson chi-square as a statistical tool in testing the hypotheses.

Table 12a: OBSERVED FREQUENCY

\begin{tabular}{|l|l|l|l|}
\hline GENDER & YES & NO & TOTAL \\
\hline MALE & 32 & 37 & 69 \\
\hline FEMALE & 54 & 27 & 81 \\
\hline TOTAL & 86 & 64 & 150 \\
\hline
\end{tabular}

Source: field survey 2016

Obtain your expected frequency from the observed frequency above using the formula

$$
\mathrm{FE}=\frac{\mathrm{CT} * \mathrm{RT}}{\mathrm{GT}}
$$

Where:

$\mathrm{FE}=$ Expected Frequency

$$
\begin{gathered}
\text { CT = Column Total } \\
\text { RT = Row Total } \\
\text { GT = Grand Total }
\end{gathered}
$$

Table 12b:EXPECTED FREQUENCY

\begin{tabular}{|l|l|l|l|}
\hline GENDER & YES & NO & TOTAL \\
\hline MALE & $\begin{array}{l}\frac{86 * 69}{150} \\
=40\end{array}$ & $\begin{array}{l}\frac{64 * 69}{150} \\
=29\end{array}$ & 69 \\
\hline FEMALE & $\begin{array}{l}\underline{86 * 81} \\
150\end{array}$ & $\begin{array}{l}\underline{64 * 81} \\
=46\end{array}$ & 81 \\
$=35$ & \\
\hline TOTAL & 86 & 64 & 150 \\
\hline
\end{tabular}

CALCULATE THE CHI-SQUARE:

Using the Chi-square test with formula $\mathrm{X}^{2}=\sum \frac{F o-F e}{F e}$

Table 12c

\begin{tabular}{|l|l|l|l|l|}
\hline Fo & Fe & $\begin{array}{l}\text { Fo- } \\
\text { Fe }\end{array}$ & $\begin{array}{l}\text { Fo- } \\
\text { Fe }^{\mathbf{2}}\end{array}$ & $\frac{(\mathbf{F o}-\mathbf{F e})^{2}}{\mathbf{F e}}$ \\
\hline 32 & 40 & -8 & 64 & 1.6 \\
\hline 37 & 29 & 8 & 64 & 2.2 \\
\hline
\end{tabular}




\begin{tabular}{|l|l|l|l|l|}
\hline 54 & 46 & 8 & 64 & 1.4 \\
\hline 27 & 35 & -8 & 64 & 1.8 \\
\hline & & & & 7 \\
\hline
\end{tabular}

$$
\begin{gathered}
\text { D.F. }=(\mathrm{c}-1)(\mathrm{r}-1) \\
=(2-1)(2-1) \\
=1 * 1 \\
=1 \\
\text { L.S. }=0.05 \\
\text { C.V. }=3.841
\end{gathered}
$$

From the test of hypothesis, the calculated Chi-square is 7; the Degree of Freedom (DF) is 1; the Level of Significance (L.S.) is 0.05; while the Critical Value is 3.841. Therefore we accept the two alternate hypotheses that states that there has been significant increase in labour migration in Gwagwalada Area Council, and that there is significant relationship between labour migration and economic development in Gwagwalada Area Council.

\section{DISCUSSION OF FINDINGS}

The study was conducted based on the distribution of questionnaires to 150 respondents across various locations/wards in Gwagwalada Area Council and the findings are no doubt very significant to the success of the study.The study has revealed that there has been a consistent increase in the population of Gwagwalada Area Council as a result of the influx of people into the area for various reasons ranging from the quest for employment, better economic condition, better healthcare service and for educational purpose. Also, the study has revealed that the population growth has impacted on the economic activities of the area in such a way that there has been increase in the purchasing capacity of the area. Similarly, the study has revealed that the increase in population has increased the available labour force in the area; however, it is significant to reiterate that the available labour cuts-across various occupational competencies such as skilled, semi-skilled and unskilled occupational specialization, but the dominant labour competency is the semi-skilled occupation which requires minimum professionalism and experience. Also, the study has revealed that the increase in population has also impacted negatively on the society, as there has been increase in criminal activities, over-population and congestion, and consequently unemployment. These negative manifestations are as a result of the mass influx of persons into the area and the competition for the scarce survival imperatives in the area.Furthermore, the study has revealed that government is not doing enough to curtail the trend of migration into the area; particularly, the rural-urban migration, and to harness the potential which the population growth provides for the economic growth and development of the area. However, in order to ensure that government key into the benefits of the population growth, it is suggested that government should provide employment opportunities, revive the agricultural sector and engage the teeming population in vocational training and other empowerment ventures. When this is done the society would have successfully harness the dividends of migration for a sustainable labour base.However, in relations to the applied theory, which is Todaro's theory of labour migration which postulates that the principal motive behind migration is centred on the wage differential among regions, and that as long as there are differences in wages earned, labour would move from low wage region to a higher wage area. This is the driving force behind rural-urban migration since there is inequality between the rural and urban sector real wage rates. This is no doubt the situation that defines the migratory pattern and motives in Gwagwalada Area Council; as people have consistently sought to better their living condition and wage situation, thus the need for migration to societies that provide such opportunities.

\section{CONCLUSION}

The study examined the correlation between labour migration and urban development from whose findings the study concludes, that there has been a consistent increase in the population of Gwagwalada Area Council as a result of the influx of people into the area for various reasons, ranging from the quest for employment, better economic conditions, better healthcare delivery services and for educational purposes. It is also important to state that, the growth in the population of Gwagwalada Area Council has impacted greatly on the economic activities of the area in such a way that there has been increase in the purchasing capacity of the area as well as the presence of medium scale businesses that have provided employment for some semi-skilled and unskilled labour. Similarly, the increase in population has brought about increase in the available labour force/manpower in Gwagwalada Area Council. However, it is important to note that the available labour/manpower cuts-across various occupational competencies such as skilled, semi-skilled and unskilled occupational specialization, but the dominant labour/manpower competency is the semi-skilled occupation which requires minimum professionalism and experience. Regardless of the benefits of population growth stated 
above, it is worthy to note to state that the increase in population has also impacted negatively on the society, as there has been increase in criminal activities, over-population and congestion, pressure on existing infrasture such as electricity, water, health institutions, roads, housing and accomodation and consequently unemployment. These negative manifestations are as a result of the mass influx of persons into the area and the competition for the scarce survival imperatives in the area.

\section{RECOMMENDATIONS}

1. There is urgent need for the government in this country to increase discriminatory investments in the rural areas in terms of provision of infrastructural facilities such as good network of roads, electricity, pipe-borne water, irrigation schemes, tourist centres, health care and educational facilities in order to encourage movement of people from the congested urban areas into the hitherto neglected and deprived rural areas and by so doing it will improve spatial balance in our developmental efforts.

2. A concerted effort should also be made towards financing the rural enterprises and encouraging effective and efficient agricultural activities through National Policy Framework and Rolling Plans. This would assist in increasing the productivity of the rural societies. Persistent efforts towards improving the urban areas without converting the rural areas would aggravate the already problematic situation posed by rural-urban migration, since higher number of youths will migrate to the more attractive urban areas.

3. Government in collaboration with the private sector could make and implement programmes for rural upliftment such as health care programmes, housing, electricity, water supply, good roads etc. So that they will not have interest in migrating to urban areas.

4. Institutions of higher learning should be established in rural areas and should be properly funded in order to discourage the rural dwellers from migrating to the cities in the quest for higher education; thus, constituting a challenge to the urban centres.

\section{REFERENCES}

[1] Adebayo, A. (1989). Youth Unemployment and National Directorate of Employment and Self Employment Programmes. Lagos: Nil Publications.

[2] Adedeji, A. and Rowland, L. (1984): Management Problems of Rapid Urbanization in Nigeria. Ile-lfe: University of Ife press. Pp. 8 and 218.

[3] Adefolalu, A. A. (1977). The Significance of Transportation in Rural Development: Omolade, Adejuyigbe and Frederick M. Helleiner (eds): Environmental and Spatial Factors in Rural Development in Nigeria. Pp. $158-164$.

[4] Adejugbe, M. A. (2004). Industrialization, Urbanization and Development in Nigeria: An Introduction in Industrialization, Urbanization and Development in Nigeria 1950-1999. Concept Publications Limited. Pp. 11, 15-16.

[5] Adepoju, A. (1990). State and Review of Migration in Africa. In the Conference on Role of Migration in African Development: Issues and Policies for the '90s, vol.1, commissioned paper, Dakar Senegal, Union for African Population Studies. Pp. 3-44.

[6] Adewale, J. G. (2005). Socio - Economic Factors Associated with Urban-Rural Migration in Nigeria: A case study of Oyo State, Nigeria. Department of Agricultural Economics and Extension, Faculty of Agricultural Sciences, Ladoke Akintola University on Technology, Ogbomoso, Nigeria. pp. 1, 14-15. JHE-17-1-013-016-2005-1203-Adewale-J-G.PDF

[7] Afolabi, M.O (2007) Rural-urban Migration and Produtiity in the Nigerian Agricultural Sector. An unpublished MPP project work, Simon Fraser University, Burmaby, BC., Canada.

[8] Agesa, R. \& Kim, S. (2001). Rural to Urban Migration as Household Decision: Evidence from Kenya. Review of Development Economics. (5) 60-75.

[9] Akinyele, O. (2005) "Poverty, Malnutrition and the Public Health Dilemma of Ibadan Postgraduate School Interdisciplinary Research Discourse 2005. Ibadan

[10] Akinyemi, A. I ; Olaopa O; Oloruntimehin O; (2000). Migration Dynamics and Changing RuralUrban Linkages in Nigeria. Obafemi Awolowo University, Ile Ife.

[11] Banerjee B. (1984). Information flow, expectations and job search: Rural-to- Urban migration process in India. Journal of Development Economics. 15 Pp. 239-257.

[12] Banerjee B. and Bucci, G. (1995). On the job search in a developing country: An Analysis based on Indian data on migrants. Economic Development and Cultural Change, 43 (3) pp. 565-583.

[13] Baril, R., Joel G., and Rulx-leonel J. (1986). Exodus as a Strategy of Survival: The Case of Rural Haiti, Environnement Caraibe, No 2, 69-104.

[14] Braunvan, J. (2004). Towards a renewed focus on rural development, Agriculture and Rural Development 11(2) pp. 4-6. 
[15] Brocherhoff, M. (1995). Fertility and Family Planning in Africa Cities: The Impact of Female Migration, Journal of Biosocial Science, Vol. 27, 347- 358.

[16] Bryan, P. (1994). Econometric. Palgrave Publishers, pp. 98.

[17] Chikere, P.I. (2014). Self Reliant Development Strategy and Rural Poverty Reduction in Ohaji/Egbema L.G.A in Imo state, Nigeria. An unpublished M.Sc. thesis. Department of Sociology, Imo State University, Nigeria

[18] Connell, J., Dasgupta B., Laishly R., Lipton M. (1977). Migration from Rural Areas: Evidence from Village studies. Oxford University Press, New Delhi.

[19] Dao, M. (2002). Determinants of Internal Migration in Developing Countries. Studi Economici. 77, 35 51. Eastern Illinois University.

[20] De Haas, H. (2007) Remittances, Migration and Social Development: A Conceptual Review of the Literature of Social Policy and Development. Programme Paper Number 34. United Nations Research Institute for Social Development.

[21] De Haas, H. (2008), The International Dynamics of Migration Processes. International Migration institute

[22] Ekong, E. E. (2003). Rural sociology. An introduction and analysis of rural Nigeria. 2nd ed. Uyo, Nigeria: Dove International Publishers

[23] Fadayomi, T. O, Titilola, S. O., Oni, B and Fapohunda, O. J. (1992). Migration, Development and Urbanization Policies in Sub-Saharan Africa. CODESRIA, Darkar.

[24] Gbemiga, A. J. (2005) Socio-Economic Factors Associated with Urban-Rural Migration in Nigeria: A Case Study of Oyo State, Nigeria. Journal of Human Ecology. 17(1):11.

[25] Ijere, N. J. (1994). Gender and Rural-urban Migration in the Ecuadorian Sierra, Columbia University Press, Columbia.

[26] Iwayemi, A. (2000). Nigeria's Oil Wealth: The Challenge of Sustainable Development in an Economy Dependent on Non-Renewable Natural Resources. University of Ibadan Postgraduate School 31st Interdisciplinary Research Discourse. Ibadan: University of Ibadan.

[27] Iyorakpo J. Rural-urban Migration and Physical Development Control Contravention in Yenagoa capital of Bayelsa state, Nigeria. International Journal of Social and Policy Issues. 2011; 8(1):61-71.

[28] Knodel, J. and Saengtienchai C. (2005) Rural Parents with Urban Children: Social and Economic Implications of Migration on the Rural Elderly in Thailand. Population Studies Centre Research Report 05-574.

[29] Ledent J. (1982). Rural-urban Migration, Urbanization, and Economic Development, Economic Development and Cultural Change, 30 (3), 507-538.

[30] Mabawonku, A.F. (1973). The Impact of Rural-Urban Migration on the Economy of Selected Rural Communities in Western Nigeria. Unpublished M.Sc.Thesis, Department of Agricultural Economics, University of Ibadan.

[31] Mini, S. E. (2001) "The impact of Rural-Urban Migration on Rural Economy in Rural Village" www.geofileonline.com

[32] Mora J. and Taylor J. (2005). Determinants of Migration, Destination, and Sector Choice: Disentangling Individual, Households, and Community Effects In International migration, remittances and the brain drain. Ozden and Schiff eds; the world Bank and Palgrave. Macmillan.

[33] Nwanna, C. (2004). Rural-urban Migration and Population Problems in Nigeria Cities. In Adejugbe M.O.A., editor. Industrialisation, urbanisation and development in Nigeria 1950-1999. Lagos-Nigeria: Concept publication limited.

[34] Nwokocha, E.E. (2007). Gender Inequality and Development in Nigeria: A Review on Antithesis. SouthSouth Journal of Culture and Development. Forthcoming.

[35] Okafor, E.E. (2005). Corruption and Its Socio-Economic Implications in Nigeria. Nigerian Journal of Clinical and Counselling Psychology, 11(1): 1-19.

[36] Okereke, C. (2003). Urbanization. Owerri: First World Publication

[37] Okunmadewa, F. (2001). "Poverty Reduction in Nigeria: A Four-point Demand". Annual Guest Lecture. Ibadan: University of Ibadan.

[38] Shettima, K.A. (1997). Ecology, identity, developmentalism and displacement in Northern Nigeria. In: P.E. Taylor, J. E. and Dyer, G. (2006) "Migration and the Sending Economy" A Disaggregated Rural Economy Wide Analysis Working Paper No. 06-002

[39] Todaro, M. (1976). Migration and economic development. A review of theory, evidence, methodology and research priorities. Mimeograph, University of Nairobi, Kenya.

[40] United Nations. (1980). Patterns of urban and rural population growth, New York; United Nations Department of International and Social Affairs.

[41] USAID. Urban Profile; 'Nigeria' making cities work. [Online] available: http//www.makingcitieswork.org/files/pdf/Africa/Nigeria 
Bank.

Africa

development

indicators;

2010.

Available:http://esds80.mcc.ac.uk/wds_wb/Table.Viewer/dimView.aspx.

[43] World Bank (2013). World development indicators. Washington D.C.: World Bank;

[44] Yamauchi, F. and Tanabe G. (2003). Non-market networks among migrants: Evidence

from Bangkok, Thailand. International Food Policy Research Institute, Discussion Paper No 16. 